\title{
Od recesji do reindustrializacji. Nowy priorytet rozwoju społeczno-gospodarczego Unii Europejskiej w dobie narastającej konkurencji globalnej ${ }^{1}$
}

\begin{abstract}
Wstęp
W latach 2008-2009 cała gospodarka światowa z USA i UE na czele pogrążyły się w głębokim kryzysie finansowym, który następnie dotkną realnej sfery gospodarczej, naznaczonej stagnacją lub recesją i rosnącym bezrobociem. Z perspektywy kilku kolejnych lat wypada odnotować, że istnieje wiele dowodów na potwierdzenie tezy, że Stany Zjednoczone choć powoli, to jednak skutecznie wychodzą z kryzysu, a nowe wschodzące potęgi globalne - Chiny i Indie stopniowo wracają na ścieżkę przyspieszonego rozwoju. Z ważniejszych globalnych graczy (global players), nie licząc Brazylii i Japonii (efekty tzw. abenomiki bowiem nie jednoznacznie pozytywne), jedynie Unia Europejska nadal tkwi w wyraźnej stagnacji gospodarczej. Wg wyliczeń Eurostatu w 2014 roku PKB w UE-28 wzrósł zaledwie o 1,4\%, a stopa bezrobocia wyniosła wysokie $11 \%$. Co prawda w marcu 2015 roku Eurostat bezrobocie szacował już na poziomie $9,8 \%$, ale nadal było ono odczuwalnie wyższe niż w Stanach Zjednoczonych. Jak podał amerykański Departament Pracy stopa bezrobocia w USA (poza rolnictwem), w grudniu 2014 roku wyniosła - 5,6 proc. W Europie po kilkunastu latach, jak się okazuje, raczej bezrefleksyjnej wiary w sukces ,gospodarki opartej na wiedzy", czyli opartej na sferze e-ekonomii i usługach wiedzochłonnych (KIS) oraz dostrzeżeniu błędu, jakim była zainicjowana pod koniec lat 80 . minionego wieku deindustrializacja, decydenci polityczni, zarówno na poziomie państw członkowskich, jak i instytucji wspólnotowych postanowili wrócić do idei rozwoju nowoczesnego i konkurencyjnego przemysłu. Wspomniana deindustrializacja, oznaczała przenoszenie przez europejskie korporacje pracochłonnej produkcji do „największej fabryki świata”, czyli Chin oraz innych ,rynków wschodzących” z Azji Południowej i Wschodniej. Wiązało się z utratą tysięcy miejsc pracy w przemyśle europejskim, rosnącym bezrobociem i niezadowoleniem społecznym. Analogiczna sytuacja dotyczyła polityki amerykańskiej wobec ChRL. Chiny z pozycji podwykonawcy stopniowo stawały się producentem wyrobów gotowych, coraz zresztą nowocześniejszych (,made in China” wypierane przez , created \footnotetext{
przyspieszonego rozwoju Chińskiej Republiki Ludowej" [The European Union and the accelerated development of the People's Republic of China] Konkurs: NCN OPUS 11 (16.12.2013), kierownik projektu: prof. zw. dr hab. Zdzisław Walenty Puślecki [Adam Mickiewicz University in Poznań, Faculty of Political Science and Journalism, Department of International Business Relations].
}

1 Prezentowany artykul realizowany jest w ramach grantu badawczego: „Unia Europejska wobec
\end{abstract}


in China"), które za sprawą rozmaitych praktyk dumpingowych w sferze wytwórczej, socjalnej i finansowej (znacznie niedowartościowane renminbi) stało się realną i nadal - mimo zobowiązań WTO - nie do końca uczciwą konkurencją dla produktów europejskich. Sytuacja ta powoduje wypieranie na wielu rynkach średnio i wysoko przetworzonych wyrobów europejskich przez produkty chińskie i konieczność wzmocnienia nowoczesnej bazy przemysłowej w Europie, czyli reidustrializacji gospodarki europejskiej. Do połowy roku 2014 wyraźnymi przejawami zmiany strategii unijnej stała się realizacja takich programów jak: „Small Business Act”, JASPERS (Joint Assistance to Support Projects in European Regions), JEREMIE (Joint European Resources for Micro to Medium Enterprise), jego uzupełnienia JASMINE (Joint Action to Support Micro-Finance Institutions in Europe), JESSICA (Joint European Support for Sustainable Investment in City Areas) oraz Programu ramowego na rzecz konkurencyjności $\mathrm{i}$ innowacji (Competitiveness and Innovation Framework Programme - CIP) (Najpierw; Żbik, 2015).

Wykres 1. Wskaźnik bezrobocia w państwach członkowskich Unii Europejskiej (w \%, dane z grudnia 2014)

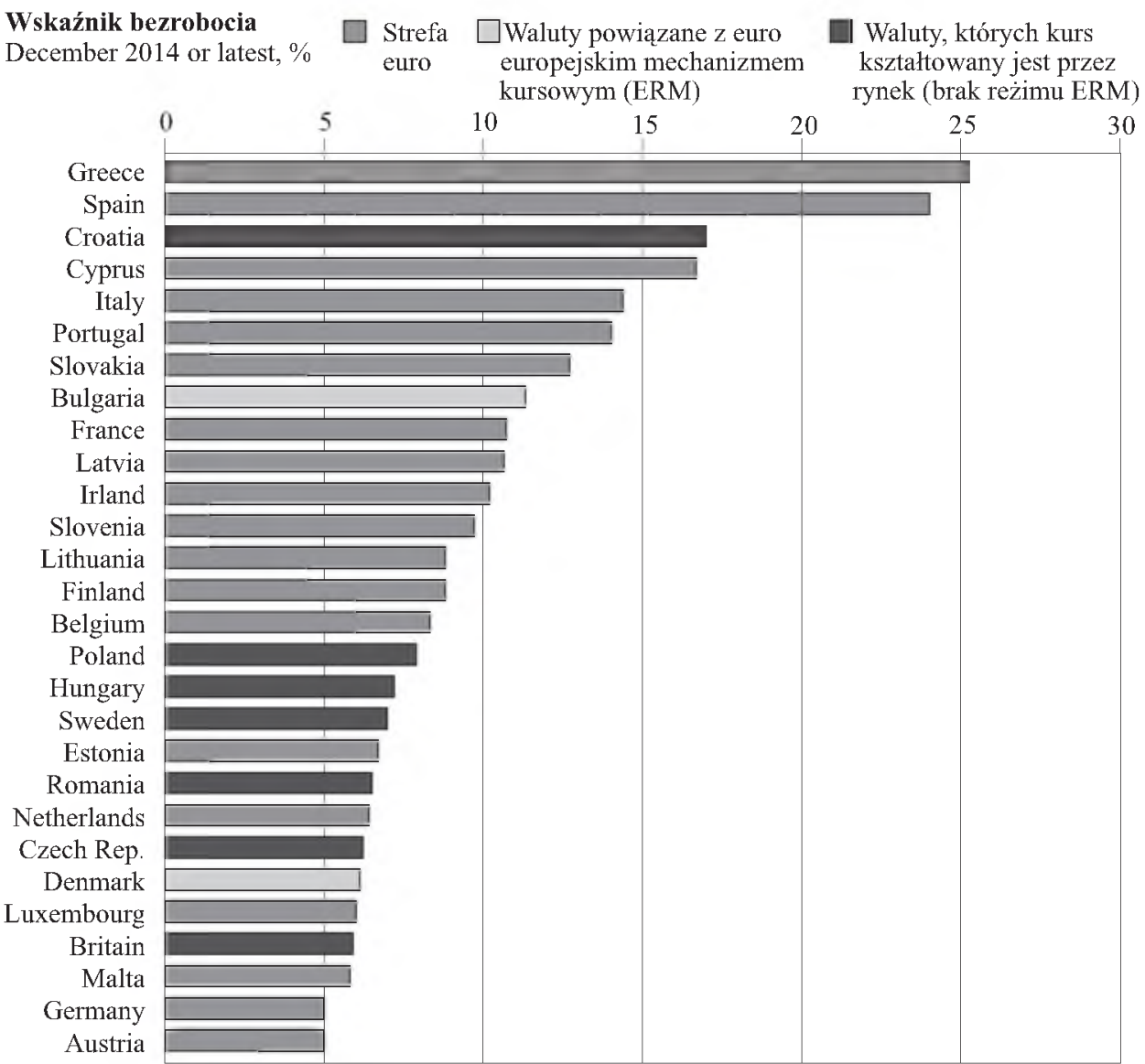

Źródło: Eurostat. 
Przeprowadzenie rewolucyjnych zmian w przemyśle stało się też priorytetem Strategii „Europa 2020” Dwie z inicjatyw przewodnich realizowanych w ramach tej strategii dotyczą sektora przemysłu. Są to:

- „Polityka przemysłowa w erze globalizacji”, której celem jest zapewnienie firmom, zwłaszcza małym i średnim przedsiębiorstwom (MŚP), lepszych warunków do prowadzenia działalności gospodarczej oraz budowanie solidnej i trwałej bazy przemysłowej, konkurencyjnej w skali światowej;

- „Unia innowacji”, której celem jest stworzenie lepszych warunków dla biznesu oraz zapewnienie firmom dostępu do finansowania badań i innowacji, tak by innowacyjne pomysły przeradzały się w nowe produkty i usługi, które $\mathrm{z}$ kolei przełożą się na wzrost gospodarczy i tworzenie nowych miejsc pracy.

Dodatkowo w 2012 roku Komisja Europejska zaktualizowała inicjatywę przewodnią w dziedzinie polityki przemysłowej zatytułowaną „Silniejszy przemysł europejski na rzecz wzrostu i ożywienia gospodarczego", której celem jest wspieranie innowacji przemysłowych i gospodarki realnej. W kolejnych latach nastapiło wyraźne przyspieszenie działań idących w kierunku reindustrializacji gospodarki europejskiej. Oprócz wymienionych, powodów aby takiej reorientacji w polityce gospodarczej UE dokonać, było aż nadto (Zrozumieć).

\section{Przyczyny priorytetowego znaczenia polityki reindustrializacji w UE}

W listopadzie 2014 roku Organizacja Współpracy Gospodarczej i Rozwoju (OECD) opublikowała kompleksowy raport na temat perspektyw rozwoju globalnej gospodarki, ostrzegając w nim, że strefie euro grozi długotrwała stagnacja, która miałaby bardzo niekorzystny wpływ na całą gospodarkę światową. Autorzy dokumentu ostrzegają, że długotrwała stagnacja w strefie euro „może pociagnąć w dół światowy wzrost i spowodować efekt domina w innych gospodarkach poprzez takie powiązania z nimi, jak finanse i wymiana handlowa". Dokument głosi, że wzrost gospodarczy w strefie euro - rdzeniu gospodarczym i finansowym UE - jest zdecydowanie za słaby i istnieje poważne ryzyko, że o ile nie wzrośnie popyt, region wpadnie w trwałą stagnację. „Gospodarka światowa rozwija się powoli, a wskaźniki wymiany handlowej i inwestycji utrzymują się na poziomie poniżej średniej, zarówno w gospodarkach zaawansowanych, jak i na wschodzących rynkach" - konstatuje OECD. Raport przewiduje co prawda niewielkie globalne przyspieszenie wzrostu gospodarczego w roku 2015, ale przy wyraźnych różnicach między poszczególnymi regionami. Najwyższa dynamika rozwojowa spodziewana jest w USA (3,1 proc. w roku 2015 i 3,0 proc. w roku 2016). Spowolnić ma natomiast wzrost gospodarczy w Chinach, który jednak w 2015 roku i tak wyniesie wysokie 7,1 proc., a rok później - 6,9 proc. Według OECD wzrost gospodarczy w strefie euro w roku 2015 zwiększy się zaledwie do 1,1 proc., a w roku 2016 do 1,7 proc. Również prognozy Fed, banku centralnego Stanów Zjednoczonych oraz prestiżowego waszyngtońskiego think tanku Brookings Institution zawierają pesymistyczne prognozy dla Europy. Niepokój tych instytucji budzi nie tylko perspektywa rozwojowa całej strefy euro, ale też ewentualne spowolnienie największej gospodarki w Europie, czyli gospodarki Niemiec (Macierewicz, 2015; The Investment; Strefie; OECD: stagnacja; Mann, 2014; Society). 
Wykres 2. Prognoza wzrostu PKB w państwach czlonkowskich Unii Europejskiej w 2015 roku (w \%, w stosunku do roku poprzedniego)

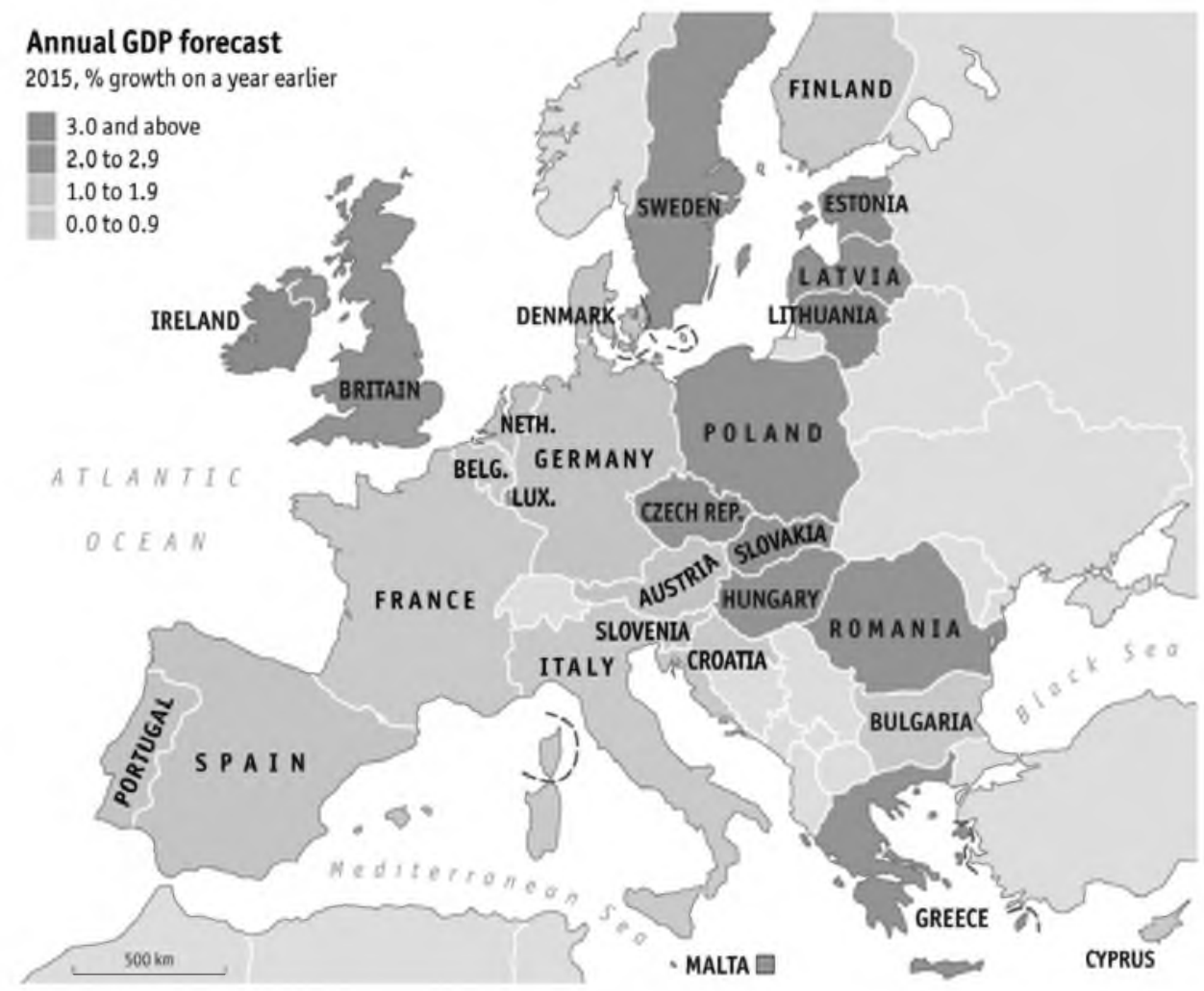

Źródlo: Eurostat.

We wrześniu 2014 roku podobnie pesymistyczne jak OECD rekomendacje dla strefy euro opracował Międzynarodowy Fundusz Walutowy i Bank Światowy. MFW w raporcie z 2014 roku - „WORLD ECONOMIC OUTLOOK Legacies, Clouds, Uncertainties", wzrost gospodarczy w USA w 2015 roku prognozuje na poziomie 3,1 proc, w Chinach na poziomie 7,1 proc., a w strefie euro na poziomie zaledwie 1,3 proc. Instytucje te zaapelowały zarazem do europejskich przywódców politycznych - zarówno na poziomie państw, jak i instytucji wspólnotowych - o pilne decyzje w sprawie pobudzenia w Europie dużych inwestycji infrastrukturalnych. Zwróciły się też do Europejskiego Banku Centralnego o niestandardowe metody ożywienia gospodarki europejskiej, co zresztą dokonało się, gdy w styczniu 2015 roku ECB podjał decyzję o interwencjonistycznej polityce monetarnej (QE - Quantitive Easing), czyli luzowaniu ilościowym. Działanie to polegało na kontrolowanym dodruku euro, czyli skupie przez ECB obligacji rządowych państw członkowskich. Wartość programu to 1,1 biliona euro, czyli około 60 miliardów euro miesięcznie, służące celowemu osłabieniu euro i podniesieniu w ten sposób międzynarodowej konkurencyjności produkcji europejskiej (Macierewicz, 2015; The Investment; Strefie; OECD; stagnacja; Mann, 2014; Societv; World). 


\section{Charakterystyka produkcji przemyslowej w Europie}

Podkreślić należy, że znaczenie gospodarcze działalności przemysłowej w Europie jest ogromne, dalece wykraczając poza procentowy, w ostatnich latach zbliżony do 15-16 proc. wkład sektora w wytwarzanie PKB. Przemysł europejski odpowiada za ponad $80 \%$ unijnego eksportu i $80 \%$ prywatnych nakładów na badania naukowe $\mathrm{i}$ innowacje. Niemal jedna czwarta miejsc pracy w sektorze prywatnym stanowią stanowiska w przemyśle, często wymagające wysokich kwalifikacji, a każde dodatkowe miejsce pracy w przetwórstwie przemysłowym prowadzi do powstania od 0,5 do 2 miejsc pracy w innych sektorach gospodarki. Przemysł europejski jest światowym liderem pod względem zrównoważonego rozwoju. Generuje nadwyżkę w wysokości 365 mld euro w handlu produktami przetworzonymi ( 1 mld euro dziennie), uzyskiwaną głównie dzięki kilku światowej klasy branżom o średnim i wysokim poziomie zaawansowania technologicznego, w których posiada przewagi komparatywne. Należą do nich branże takie jak: motoryzacyjna, maszyn przemysłowych i urządzeń precyzyjnych, sprzętu elektrycznego. Ponadto: branża transportowa, sektor farmaceutyczny i chemiczny, tytoniowy, aeronautyka i sektor przestrzeni kosmicznej, przemysł drzewny, papierniczy, media drukowane i elektroniczne oraz sektor rolno-spożywczy (szczególnie pod kątem jakości produkcji oraz w produkcji napojów). Słabiej na tle konkurencji międzynarodowej prezentuje się natomiast branża odzieżowa i tekstylna, komputerowa i elektroniczna, produkcja wyrobów skórzanych, plastikowych i gumowych, przemysł drzewny (z chlubnym wyjątkiem Polski, drugiego po Chinach producenta mebli w świecie) i rafinerii paliw. UE jest więc światowym liderem $w$ wielu sektorach produkcji o znaczeniu strategicznym i bezsprzecznie posiada duże atuty konkurencyjne $w$ sferze produkcji przemysłowej. Na przewagę konkurencyjną przemysłu europejskiego składają się: wysoko wykwalifikowani i kreatywni pracownicy, znaczny udział produkcji krajowej w eksporcie towarów (porównywalny z USA i Japonią i znacznie wyższy niż w Chinach i Korei Płd.) oraz przewaga komparatywna związana z wybranymi produktami o wysokiej jakości o średnim i wysokim stopniu przetworzenia (European Competitiveness).

Sukcesy w wybranych rodzajach produkcji przemysłowej nie oznaczały jednak braku barier i przeszkód poważnie utrudniających firmom europejskich szybki i stabilny rozwój. Kryzys 2008+ uwidocznił znaczenie gospodarki realnej i silnego przemysłu oraz jego słabnące znaczenie w UE. Od 2008 r. liczba miejsc pracy w przemyśle zmniejszyła się o prawie $4 \mathrm{mln}$, a w 2014 roku udział przemysłu w PKB zmniejszył się z $15,4 \%$ do $15,1 \%$. Wydajność produkcji w porównaniu z głównymi konkurentami UE w świecie, USA, Japonią, Chinami i Koreą Płd. systematycznie spada. Spadek udziału przemysłu w ostatnich latach w wartości dodanej wynikał głównie ze spadku względnych cen produkcji w odniesieniu do usług, które z kolei odnotowywały wolniejsze tempo spadku wydajności. Od początku roku 2008 do końca roku 2013, udział usług w UE spadł o $9 \%$ w relacji do PKB, podczas gdy produkcja przemysłowa o $12 \%$. UE nadal stosunkowo daleko jest do realizacji swego głównego celu reindustrializacji, czyli 20\% udziału przemysłu w PKB. Łączny jego udział spadł z 18,5\% w 2000 roku do nieco ponad 15\% w 2013 roku. Jedynie w ośmiu państwach członkowskich (Republika Czeska, Rumunia, Irlandia, Węgry, Słowacja, Niemcy, Słowenia i Litwa) produkcja przemysłowa stanowi ponad $20 \%$ wartości dodanej. We wszystkich pozostałych pań- 
stwach członkowskich wskaźnik ten kształtuje się poniżej tego pułapu. Z ważniejszych dla rozwoju UE gospodarek szczególnie dotyczy to Francji i Wielkiej Brytanii. Dodatkowo - Grecji i Cypru. Nadmierne jest też uzależnienie w rozwoju przemysłu od najnowocześniejszej gospodarki europejskiej, czyli gospodarki Niemiec. Wielkość produkcji przemysłowej w Europie powinna być bardziej harmonijnie rozłożona. Silna i nowoczesna baza przemysłowa we wszystkich państwach członkowskich musi więc mieć kluczowe znaczenie dla ożywienia gospodarczego i konkurencyjności w Europie (Dziatania).

\section{Wykres 3. Procentowy wklad produkcji przemyslowej w PKB państw czlonkowskich Unii Europejskiej} (porównanie danych z roku 2008 i 2013)

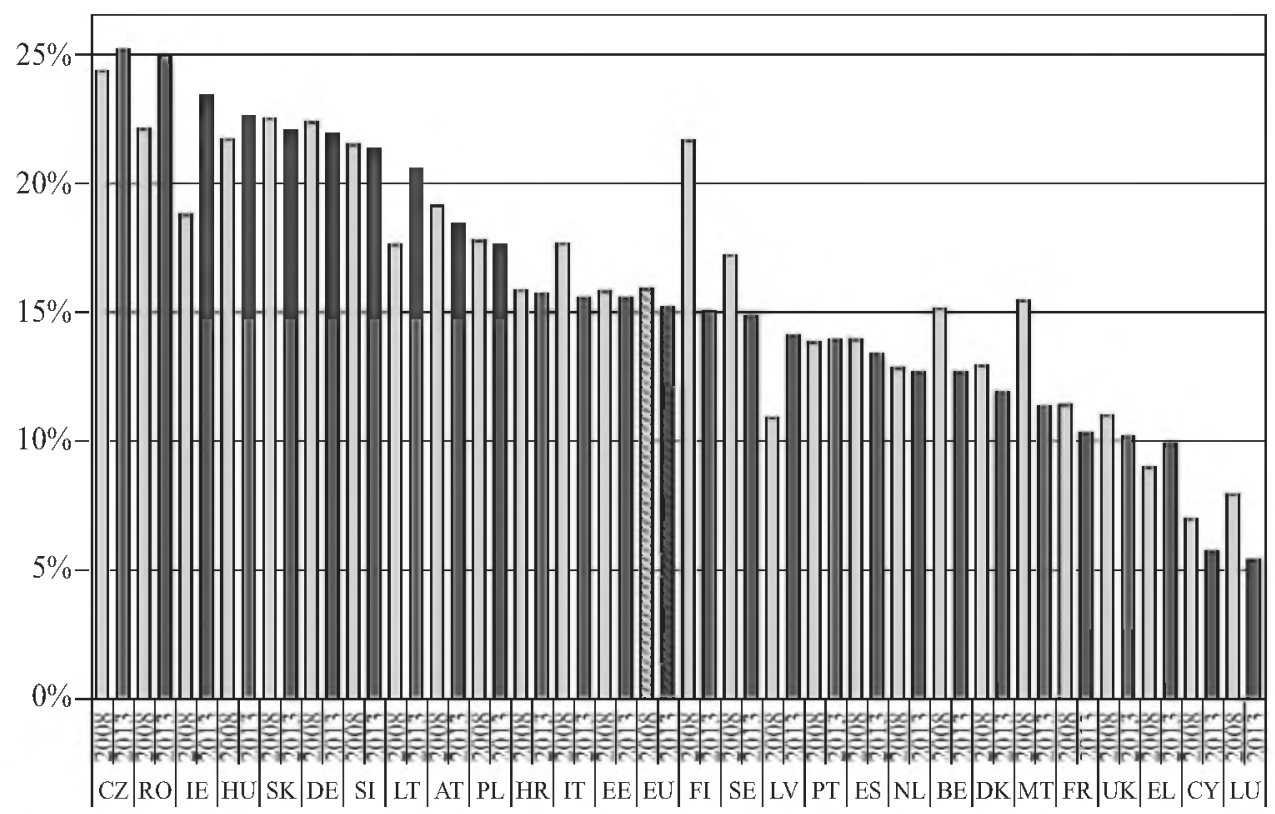

Żródło: Eurostat.

Ponadto, ze sprawozdania ,Reindustrialising Europe” z 2014 roku wynika, że wydajność pracy w przemyśle w kilku państwach członkowskich co prawda wzrosła, ale było to spowodowane zmniejszoną produkcję przy większej redukcji pracowników. W ciągu pięciu lat, licząc od 2007 do 2012 roku, tylko w Niemczech udało się zwiększyć zatrudnienie w przemyśle. W pozostałych gospodarkach zatrudnienie w gałęzi tej malało. Sprawozdanie to stanowi opartą na wskaźnikach ocenę realizacji polityki przemysłowej na szczeblu UE i krajowym, w podziale na poszczególne państwa.

Sytuację komplikuje też fakt dużych dysproporcji wewnątrz samej Unii, dotyczących mierzonego przy użyciu wielu parametrów poziomu konkurencyjności przemysłu. Ilościową ocenę konkurencyjności przemysłu UE, oprócz wymienionego, zawiera inne sprawozdanie z 2014 roku, zatytułowane „Helping Firms Grow”. Z obydwu analiz wynika, że państwa członkowskie UE pod kątem konkurencyjności można podzielić na cztery grupy: 
Wykres 4. Ilość miejsc pracy netto tworzonych w przemyśle w państwach czlonkowskich Unii Europejskiej w 1. 2007-2012 (w tys.)

ES IT FR UK RO PL PT EL CZ SE DK HU LT BE IE NL FI SK SI LV EE AT CY MT LU DE

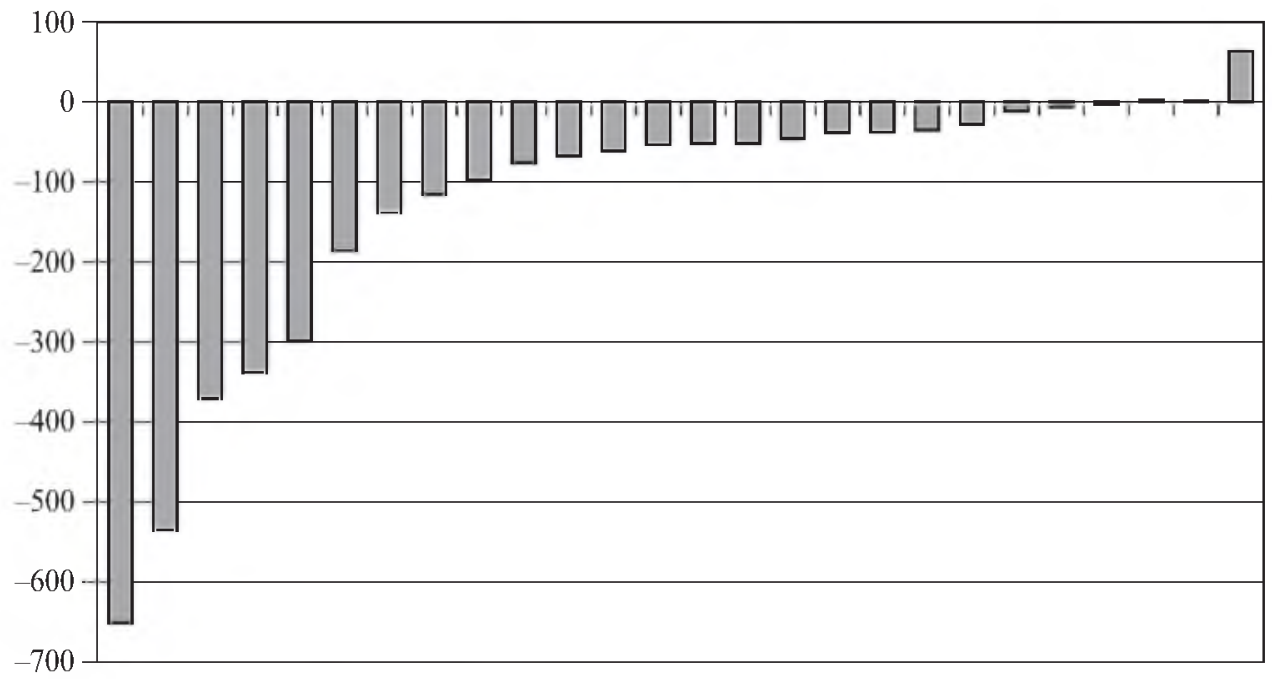

Note: Data for Bulgaria and Croatia not available.

Źródlo: Eurostat.

- gospodarki o wysokiej i zwiększającej się konkurencyjności: Niderlandy, Niemcy, Dania i Irlandia:

- gospodarki o wysokiej konkurencyjności, która jednak znajduje się w stagnacji lub maleje: Belgia, Zjednoczone Królestwo, Austria, Francja, Włochy, Luksemburg, Szwecja i Finlandia;

- gospodarki o niskiej konkurencyjności, która ulega poprawie: Estonia, Litwa, Hiszpania, Łotwa, Republika Czeska, Węgry, Polska, Portugalia, Rumunia, Słowacja i Grecja;

- gospodarki o niskiej konkurencyjności, która znajduje się w stagnacji lub maleje: Słowenia, Bułgaria, Chorwacja, Malta i Cypr.

Szczególny niepokój budzić powinien niski stan konkurencyjności gospodarki hiszpańskiej oraz malejąca konkurencyjność przemysłu brytyjskiego, francuskiego i włoskiego (Konkurencyjność).

\section{Charakterystyka głównych działań przyjętych w UE na rzecz realizacji wizji "uprzemysłowionej Europy"}

W związku z tak skonstruowaną diagnozą oraz dużym i nie w pełni wykorzystanym potencjałem przemysłowym, Jean-Claude Juncker, jeszcze jako kandydat na urząd przewodniczącego Komisji Europejskiej, w lipcu 2014 roku zaproponował program na rzecz zatrudnienia, wzrostu gospodarczego, sprawiedliwości i zmian demokratycznych, będący swoistym przeglądem założeń i realizacji Strategii Europa 2020. Komisja Europejska za swoje najważniejsze zadanie uznała pokryzysową odbudowę w Europie, 
przywrócenie zaufania europejskich obywateli do idei integracji, skoncentrowanie polityki na najistotniejszych wyzwaniach, przed którymi stoją gospodarki państw członkowskich i ich społeczeństwa, jak również wzmocnienie legitymacji demokratycznej UE. Odnowiona współpraca związana jest ze wszystkimi państwami w strefie euro i poza nią w ramach Unii oraz z innymi państwami w ramach strefy Schengen. Podkreśla się przy tym, że Traktaty dopuszczają możliwość dochodzenia do wspólnych celów różną prędkością i w ramach różnych ustaleń. W swoim programie J. C. Juncker koncentruje się na dziesięciu kluczowych obszarach polityki. Jeden z kluczowych jego elementów to pogłębiony i bardziej sprawiedliwy rynek wewnętrzny, oparty na wzmocnionej bazie przemysłowej. W praktyce oznacza to znaczące zwiększenie udziału przemysłu w unijnym PKB z 15 do 20 proc. do 2020 roku. W opinii J. C. Junckera powinno to pozwolić Europie utrzymać pozycję światowego lidera w strategicznych sektorach gospodarki, takich jak: sektor motoryzacyjny, aeronautyka, inżynieria, programy kosmiczne, chemikalia i przemysł farmaceutyczny. Inne kluczowe aspekty to: stymulowanie inwestycji w nowe technologie, poprawa otoczenia biznesu, ułatwiony dostęp do rynków i do finansowania, zwłaszcza dla sektora MŚP; bardziej restrykcyjna kontrola nad bankami za pomoca jednolitego mechanizmu nadzorczego oraz jednolitego mechanizmu ich restrukturyzacji i uporządkowanej likwidacji; uzupełnienie przepisów dotyczących banków unią rynków kapitałowych, co obniżyć ma koszt pozyskania kapitału, zwłaszcza dla MŚP, pomóc w zmniejszeniu bardzo dużej zależności gospodarki europejskiej od finansowania bankowego oraz zwiększyć atrakcyjność Europy jako miejsca do inwestowania; promocja mobilności pracowników, zwłaszcza w tych obszarach, gdzie stale odnotowuje się braki siły roboczej i niedopasowanie umiejętności zawodowych do potrzeb rynku; rygorystyczne wdrożenie dyrektywy o delegowaniu pracowników i eliminacja dumpingu socjalnego w Unii Europejskiej. Ostatni element stanowi walka $\mathrm{z}$ unikaniem opodatkowania i oszustwami podatkowymi, wraz z praniem brudnych pieniędzy (Juncker, 2014).

W dobie postępującej globalizacji, coraz większej konkurencji globalnej ze strony rynków wschodzących z Chinami i Indiami na czele oraz odbudowie gospodarczej i finansowej w USA, Komisja słusznie dostrzegła, że długotrwały dobrobyt gospodarczy w Europie głównie zależał będzie od siły europejskiego przemysłu, a w mniejszym stopniu od sektora usług i banków. Uczyniła to co prawda przynajmniej dziesięć lat za późno, ale ważne że do konstatacji takiej w ogóle doszło. Dlatego też UE za wiodące zadanie do roku 2020 postawiła sobie wizję reindustrializacji, czyli wspieranie konkurencyjności przemysłu i przedsiębiorstw unijnych, zwiększanie w nich zatrudnienia i pobudzanie wzrostu gospodarczego poprzez stwarzanie warunków sprzyjających przedsiębiorczości, zwłaszcza w sektorze MŚP (Opinia Europejskiego) ${ }^{2}$.

2 Rdzeniem produkcji przemysłowej w UE jest sektor małych średnich przedsiębiorstw (MŚP). Firmy tego typu stanowią $98 \%$ przedsiębiorstw w Unii, zapewniają $67 \%$ istniejących miejsc pracy w sektorze prywatnym. Ponadto przypada na nie aż $80 \%$ nowo powstalych miejsc pracy. Generująrównież ponad połowę calości wartości dodanej tworzonej przez przedsiębiorstwa w UE. MŚP stanowią więc kluczowy czynnik pobudzający wzrost gospodarczy, zatrudnienie i integrację społeczną. Wpływ na ograniczoną konkurencyjność MŚP w świecie ma niskie umiędzynarodowienie ich dzialalności na obszarze Europy i poza nią. Według szacunków, aktualnie zaledwie 25\% unijnych MŚP prowadzi bądź prowadziło działalność eksportową. Zaledwie $13 \%$ z nich regularnie eksportowało poza granice 
W komunikacie prasowym z września 2014 roku KE podkreśla, że aby wzrost gospodarczy w Europie nie został zahamowany, UE i państwa członkowskie muszą w trybie pilnym rozwiązać szereg niepokojących problemów. Zaliczono do nich: zapewnienie wzrostu inwestycji (skuteczniejsze innowacje i komercjalizacja badań oraz dostęp do wysoko wykwalifikowanej siły roboczej); lepszy dostęp firm do finansowania (latwiejszy kredyt bankowy dla sektora MŚP i pozabankowe źródła finansowania); sprawniej działającą administrację publiczną (czasochłonne i kosztowne przepisy podatkowe, korupcja i nieskuteczne systemy wymiaru sprawiedliwości uznaje się za najbardziej szkodliwe dla rozwoju przedsiębiorstw); stworzenie szerszego dostępu przedsiębiorcom do rynków zagranicznych oraz poprawę innowacyjności produkcji i zapewnienie niższych cen energii (prądu i gazu) (Opinia Europejskiego).

Na poziomie instytucji wspólnotowych, Komisji, Rady UE i PE nie bez przyczyny szybko zrozumiano, że głównym instrumentem służącym do urzeczywistnienia wizji nowoczesnej, konkurencyjnej i uprzemysłowionej Europy nadal pozostać musi sprawnie funkcjonujący, spójny i dynamiczny Jednolity Rynek, dysponujący ponad $500 \mathrm{mln}$ konsumentów, $220 \mathrm{mln}$ pracowników i $21 \mathrm{mln}$ przedsiębiorców. Zintegrowany Jednolity Rynek ewoluować ma w tej materii w kierunku doprowadzenia do stworzenia: pełnej i zintegrowanej infrastrukturalnej sieci informacyjnej, energetycznej i transportowej; otwartego i zintegrowanego rynku wewnętrznego towarów i usług oraz przyjaznego otoczenia administracyjnego i prawnego dla biznesu, w tym przejrzystych ram regulacyjnych. Z punktu widzenia realizacji idei reindustrializacji konieczne jest przy tym wydatne zwiększenie produktywności przemysłu wytwórczego i związanych z nim usług. Ważne jest też określenie strategicznych europejskich priorytetów przemysłowych. Nieskoordynowane działania w ramach polityki krajowej muszą zostać zastapione spójną strategią w ramach europejskiej polityki przemysłowej. Szczególnie dotyczy to sektora MŚP i usług około biznesowych (BPO) z nim związanych (Polityka Przemystowa).

$\mathrm{Na}$ przestrzeni ostatnich 4-5 lat Komisja wielokrotnie sygnalizowała, że Europa pilnie potrzebuje nowoczesnej polityki przemysłowej, która będzie wspierała przedsiębiorstwa - zwłaszcza małe i średnie - w reagowaniu na zmiany, jakie niosą ze sobą procesy globalizacji, skutki bieżącego kryzysu gospodarczego oraz konieczność przejścia na gospodarkę niskoemisyjną (pakiet klimatyczno-energetyczny UE). Słusznie uznaje ona przy tym, że europejski sektor farmaceutyczny, maszynowy, budowlany, motoryzacyjny, chemiczny i lotniczy oraz rolno-spożywczy (pod kątem jakościowym) nadal posiadają wysoki poziom konkurencyjności międzynarodowej. Problemy przeżywa przede wszystkim przemysł włókienniczy, odzieżowy i skórzany, który w wyniku nie zawsze uczciwej konkurencji państw azjatyckich (Chiny, Kambodża, Bangladesz) i la-

Unii i tylko 2\% przedsiębiorstw tego typu inwestowało poza krajem pochodzenia. Ponadto w badaniu Eurobarometru z 2012 r. wykazano niewykorzystany potencjal w zakresie wzrostu MŚP - na rynkach ekologicznych w Unii i poza jej granicami - pod względem umiędzynarodowienia i dostępu do zamówień publicznych. Kolejnym czynnikiem wplywającym na konkurencyjność jest stosunkowo słaby duch przedsiębiorczości (entrepreneurship) w UE. Zaledwie $45 \%$ obywateli państw Unii (i mniej niż $40 \%$ kobiet) chciałoby pracować na własny rachunek. W Stanach Zjednoczonych wskaźnik ten wynosi 55\%, a w Chinach - 71\%. 
tynoamerykańskich (Gwatemala, Honduras, Salwador) wymaga ciągłej restrukturyzacji. Głównym wyzwaniem staje się też poprawa innowacyjności produkcji, czyli rozwinięcie i wprowadzenie na rynek europejskich technologii wspomagających rozwój przemysłowy (typu: biotechnologia przemysłowa, nanotechnologia, fotonika, mikro- i nanoelektronika). Główną siłą napędową innowacyjności i konkurencyjności gospodarki europejskiej - w projekcji Komisji - stać się ma kosmonautyka. Z jednej strony Europa posiada wielki i zaawansowany technologicznie przemysł kosmiczny, który zaspokaja znaczną część światowego zapotrzebowania komercyjnego w dziedzinie produkcji, wystrzeliwania i eksploatacji satelitów. Dostarcza też systemy i świadczy usługi z dziedziny telekomunikacji, nawigacji i obserwacji Ziemi, które zapewniają bezpieczeństwo członkom Unii i pomagają sprostać głównym wyzwaniom społecznym takim jak zmiany klimatyczne. Dzięki systemowi GNSS (globalny system nawigacji satelitarnej), Galileo/EGNOS (europejski system wspomagania satelitarnego) i programowi GMES (globalny monitoring środowiska i bezpieczeństwa) oraz infrastrukturze łączności satelitarnej zwiększać może się konkurencyjność różnych gałęzi przemysłu oraz rozwijać rynek produkcji i usług związanych z kosmonautyka, zwłaszcza nowych usług satelitarnych. Według KE aż 800 mld euro (6-7 proc. PKB UE) zależy od systemów nawigacji satelitarnej. Dotychczas jednak systemy te pozostają poza europejską kontrolą (głównie amerykański GPS). Z drugiej jednak strony UE nadal we wszystkich tych projektach ma spore opóźnienia i nadal występują w Europie różne bariery finansowe i decyzyjne w tej sferze aktywności. W sierpniu 2014 roku z kosmodromu w Gujanie Francuskiej rosyjska rakieta Sojuz co prawda wyniosła na orbite kolejne dwie unijne satelity, jednak niedługo później Europejska Agencja Kosmiczna (ESA - European Space Agency) podała, że zostały one... ulokowane na niewłaściwych orbitach. To symboliczne wydarzenie było tylko niechlubnym zwieńczeniem ciagu europejskich problemów technicznych, finansowych i decyzyjnych związanych z systemem Galileo/EGNOS. Europejski przemysł kosmiczny zaczęto nazywać... komicznym. Silna i narastająca konkurencja globalna w tej dziedzinie ze strony USA, Indii, Rosji, a w ostatnich latach szczególnie Chin wymaga ewidentnego wzmocnienia wsparcia finansowego i administracyjnego dla tej gałęzi przemysłu europejskiego. Aeronautyka i przemysł kosmiczny muszą pozostać europejskim priorytetem w kolejnych dekadach. Europa powinna posiadać równoważną do amerykańskiego systemu GPS i rosyjskiego GLONASS alternatywę, w dodatku cywilną a nie wojskową (Polityka Przemystowa).

Dodatkowo przynajmniej dwa inne sektory produkcji europejskiej wymagają szczególnej uwagi i wsparcia. UE jest światowym liderem w dziedzinie produkcji samochodów. Dlatego też ta dziedzina przemysłu ma zasadnicze znaczenie dla poprawy sytuacji gospodarczej w Europie. Sektor motoryzacyjny zatrudnia tysiące wykwalifikowanych pracowników, pobudza rozwój wiedzy i innowacji w innych branżach. Ponadto wnosi duży wkład w zagregowany unijny PKB, wyniki eksportu netto i wskaźniki inwestycji prywatnych w Europie. Innym sektorem o priorytetowym znaczeniu w Europie jest turystyka. Przemysł turystyczny wytwarza bezpośrednio ponad 5 proc. PKB Unii Europejskiej. W jego skład wchodzi około 1,8 $\mathrm{mln}$ firm, które zatrudniają około 5,2 proc. ogółu siły roboczej (około 9,7 $\mathrm{mln}$ miejsc pracy). Pośrednio zapewnia on niemal 12 proc. miejsc pracy. Wspierając różnorodność i jakość swojej oferty turystycz- 
nej, UE dąży do tego, aby Europa nadal była najpopularniejszym celem wypraw turystów $\mathrm{z}$ całego świata (Zrozumieć) $)^{3}$.

Aby posiadać wiodącą w świecie pozycję w przemyśle Europa potrzebuje produkcji innowacyjnej oraz rosnących inwestycji w dobrze rokujące i strategiczne technologie produkcyjne. Przedsiębiorstwa zyskujące na podnoszeniu innowacyjności, wydajności i konkurencyjności szerzej nastawione są bowiem na tworzenie nowych miejsc pracy. Wg wyliczeń Komisji każde 1 euro zainwestowane na ten cel w przedsiębiorstwie generuje około 13 euro wartości dodanej, a dalszy wzrost inwestycji do poziomu 3\% PKB do roku 2020 przełoży się na powstanie kolejnych $3,7 \mathrm{mln}$ miejsc pracy. Zintegrowany i uproszczony charakter programu „Horyzont 2020” zwiększyć ma udział MŚP w tej dziedzinie o co najmniej $20 \%$ ( $8,65 \mathrm{mld}$ euro) w połączonych budżetach priorytetów: „Wiodąca pozycja w zakresie technologii wspomagających i przemysłowych" i ,Wyzwania społeczne". Małe i średnie przedsiębiorstwa zyskały więc znaczące miejsce w tym programie. Mogą podejmować współpracę w ramach projektów jako członkowie konsorcjum oraz pozyskiwać wsparcie za pośrednictwem kredytów i gwarancji. Dostępne jest także dofinansowanie szkoleń biznesowych i doradztwa w celu rozpoznania i zainteresowania inwestorów prywatnych. Wsparcie tego typu przyciagnąć ma środki prywatne ze sfery venture capital do badań i innowacji. Szacuje się, że każde 1 euro zainwestowane przez UE na ten cel wygeneruje 5 euro dodatkowych funduszy. Różnica w stosunku do USA pod tym względem jest bowiem wyraźna. W Stanach Zjednoczonych $2 / 3$ amerykańskich inwestycji w produkcję jest finansowane poza sektorem finansowym, a w Europie zaledwie 1/3 (Horizon 2020 w skrócie).

Przepisy unijne i krajowe, obecnie zbyt restrykcyjne i biurokratyczne w tej dziedzinie powinny więc znacznie lepiej sprzyjać większemu napływowi kapitału typu private equity/venture capital, do gospodarki europejskiej, w szczególności w celu wspierania innowacji. $Z$ procesami przemysłowymi nierozerwalnie związany jest, wzmacniający ich baze, sektor usług. Stanowi on $70 \%$ gospodarki europejskiej i zatrudnia największą część siły roboczej. Problematyczne wdrażanie dyrektywy usługowej powoduje jednak brak zintegrowanego rynku usług w Europie, co ma negatywny wpływ zarówno na handel wewnątrzwspólnotowy (intra-EC trade), jak i na produktywność gospodarki. W obu tych dziedzinach USA zajmuje wiodącą pozycję w świecie ze względu na swój znacznie bardziej zintegrowany rynek usług. Ten aspekt także wymaga więc poprawy w UE (Horizon 2020 w skrócie).

Nadmienić w tym miejscu wypada, że wspomniany pakiet środków o wartości 80 mld euro na rzecz rozwoju badań naukowych, innowacji i konkurencyjności w Europie, pod nazwą „Horyzont 2020”, Komisja Europejska przedstawiła w listopadzie

3 Ciekawsze inicjatywy KE w tej dziedzinie to: Unijny program turystyki socjalnej „Calypso”, który umożliwia niektórym grupom docelowym, np. seniorom, którzy stanowią duży potencjalny rynek, wyjazd na wakacje poza sezonem do innego kraju UE; doroczna impreza „Crossroads of Europe” poświęcona turystyce kulturalnej, promująca miejsca oraz szlaki, które są symbolami spotkania różnych kultur; projekt „Modelowe Ośrodki Turystyczne Europy” (EDEN) promujący mało znane ośrodki turystyczne zaangażowane w zrównoważony rozwój społeczny, kulturalny i środowiskowy; inicjatywa „50 000 turystów” jako innowacyjna forma współpracy między Ameryką Południową i Europa, której celem jest promowanie podróży poza sezonem, przy wykorzystaniu wolnych miejsc w samolotach i hotelach. 
2011 roku. Program ten, w opinii komisarz Máire Geoghegan-Quinn stanowi pierwszą inicjatywę skupiającą wszystkie unijne środki finansowania badań naukowych i innowacji. Dotyczy on przede wszystkim planu przekształcania odkryć naukowych w innowacyjne produkty i usługi, które otworzą nowe możliwości dla przedsiębiorstw i poprawiąjakość życia i pracy. Fundusze programu „Horyzont 2020” przeznaczone są na trzy główne cele. Po pierwsze, program ma wspierać czołową pozycję UE w nauce dzięki budżetowi w wysokości 24,6 mld euro (obejmującemu 77-procentowe zwiększenie środków na rzecz Europejskiej Rady ds. Badań Naukowych). Po drugie, program zakłada zapewnienie europejskim przedsiębiorcom wiodącej pozycji w zakresie innowacji przemysłowych, na co przeznaczono $17,9 \mathrm{mld}$ euro. Obejmuje to znaczące inwestycje w wysokości 13,7 mld euro w najważniejsze technologie, a także lepszy dostęp do kapitału oraz wsparcie dla MŚP. Po trzecie, 31,7 mld euro przeznaczono na ważne kwestie dotyczące wszystkich mieszkańców państw członkowskich UE, które podzielono na sześć głównych zagadnień: zdrowie, zmiany demograficzne i dobrostan; bezpieczeństwo żywnościowe, zrównoważone rolnictwo, badania morskie oraz gospodarka ekologiczna; bezpieczna, ekologiczna i efektywna energia; inteligentny, ekologiczny i zintegrowany transport; działania w dziedzinie klimatu, efektywna gospodarka zasobami i surowcami; integracyjne, innowacyjne i bezpieczne społeczeństwa.

W ramach programu „Horyzont 2020” zaplanowano inwestycje rzędu prawie $6 \mathrm{mld}$ euro w rozwój europejskiego potencjału przemysłowego, w dziedzinie kluczowych technologii wspomagających, które obejmują: fotonikę oraz mikro- i nanoelektronikę, nanotechnologie, materiały zaawansowane oraz zaawansowane systemy produkcji i przetwarzania, a także biotechnologię i technologie cyfrowe (Horyzont 2020-program).

Jak podkreśla KE: „Podstawowe znaczenie dla wzrostu wydajności przemysłu europejskiego mają w szczególności technologie cyfrowe. Ich potencjał w zakresie przekształceń i rosnący wpływ na wszystkie sektory definiuje na nowo tradycyjną działalność gospodarczą i modele produkcyjne. Technologie te doprowadzą do powstania szeregu nowych produktów, w szczególności wprowadzania przez przemysł innowacji w dziedzinie usług («przechodzeniem przemysłu na usługi», ang. «servitization of industry»). W całej gospodarce światowej przeprowadzana jest obecnie digitalizacja i polityka przemysłowa musi uwzględniać nowe możliwości technologiczne, takie jak: chmury obliczeniowe, duże zbiory danych i rozwój łańcucha wartości danych, nowe przemysłowe zastosowania internetu, inteligentne zakłady produkcyjne, robotyka, drukowanie i projektowanie trójwymiarowe" (Działania).

Innowacyjny przemysł wymaga jednak nie tylko silnej i nowoczesnej bazy technologicznej, ale też odpowiednich umiejętności i kwalifikacji zawodowych pracowników. W UE słusznie więc poświęca się coraz większą uwagę edukacji, szkolnictwu różnego szczebla i szkoleniom, za priorytet uznając kształcenie techniczne (szkoły średnie i ośrodki szkolenia zawodowego, w tym rzemiosło). Nie przypadkiem bowiem najsilniejszy przemysł i najniższe wskaźniki bezrobocia wśród młodzieży odnotowują Niemcy, Austria i Holandia, gdzie dobrze funkcjonuje dualny system kształcenia, rozwinięte jest kształcenie zawodowe a studia wyższe nadal mają względnie elitarny charakter oraz Dania, ze znakomicie funkcjonującym modelem flexicurity.

Zmieniające się otoczenie globalne i narastająca konkurencja w produkcji wyrobów nowoczesnych wymaga więc od państw członkowskich UE stałego podnoszenia kwa- 
Wykres 5. Wskaźnik bezrobocia wśród ludzi młodych w państwach czlonkowskich Unii Europejskiej (w \%, dane z grudnia 2014)

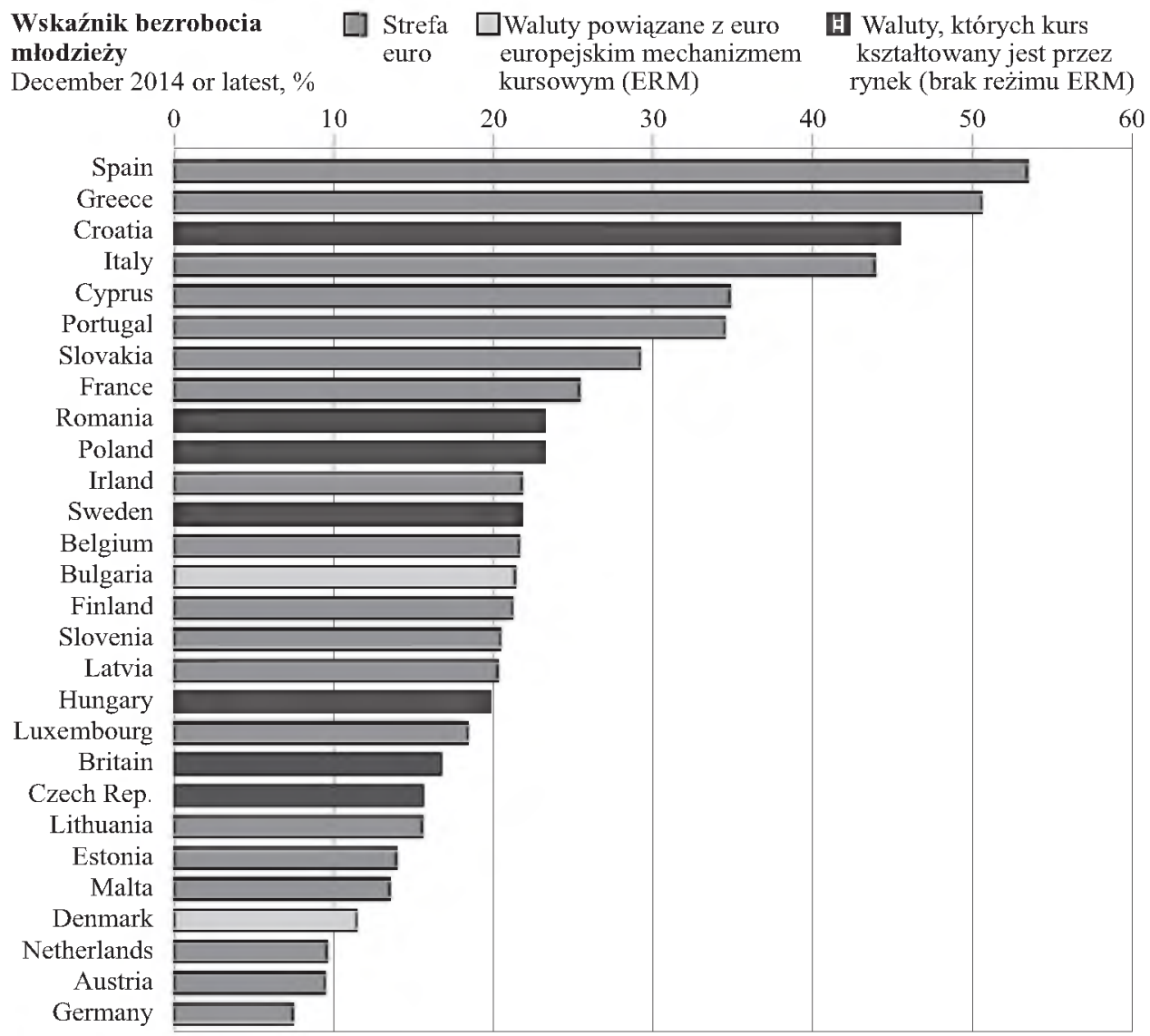

Źródto: Eurostat.

lifikacji i dopasowywanie umiejętności pracowniczych do potrzeb przedsiębiorstw. Braki w tej dziedzinie istnieją bowiem w całej Europie. Pomimo konkurencyjnych stawek płac pozostaje wiele wolnych miejsc pracy, które z powodu braku odpowiednich kwalifikacji zawodowych nie mogą być obsadzone. W badaniu z 2013 roku, 39\% firm europejskich odnotowano trudności ze znalezieniem pracowników o odpowiednich kwalifikacjach, w porównaniu z 36\% w 2008 i 35\% w 2005 roku. Problemy ze znalezieniem odpowiednio wykwalifikowanych pracowników najbardziej powszechne są w sektorze produkcyjnym (43\%), a najrzadziej w sektorze usług finansowych (30\%). Ponad 60\% zakładów w Austrii i krajach bałtyckich Unii ma problemy z zatrudnieniem pracowników o odpowiednich kwalifikacjach. Chorwacja, Cypr, Grecja i Hiszpania ze wskaźnikiem poniżej 25\% na tym tle prezentują się najlepiej, ale też dysponują znacznie niższym potencjałem innowacyjności (Progress in industrial).

Wedhug Europejskiego Komitetu Ekonomiczno-Społecznego należy też zająć się problemem strukturalnego niedoboru na uczelniach wyższych naukowców w zakresie nauk ścisłych, głównie inżynierów, matematyków oraz studentów (Opinia Europejskiego). 
Wykres 6. Poziom trudności w znalezieniu pracy dla pracowników wykwalifikowanych w państwach czlonkowskich Unii Europejskiej (w \%, dane z roku 2013)

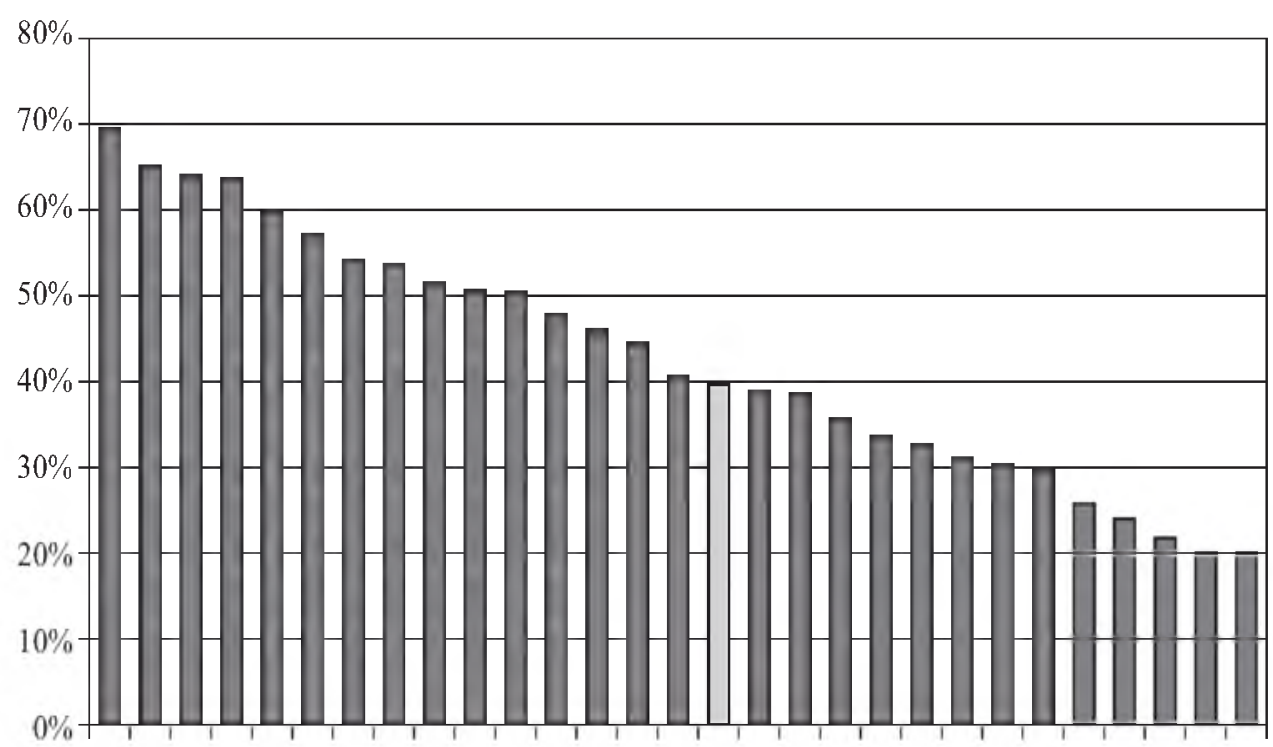

EE LV LT AT BE HUBGMTDE SE FR FI LU CZ SK EU RO PT PL DK IE NL SI IT UK ES EL HR CY

Źródto: Eurostat.

Rozwinięciem wcześniej podjętych działań UE stało się powołanie Europejskiego Funduszu na rzecz Inwestycji Strategicznych (European Fund for Strategic Investment - EFSI) oraz realizacja programu COSME (Programme for the Competitiveness of Enterprises and small and medium-sized enterprises). W listopadzie 2014 roku Komisja zaprezentowała kompleksowy program pobudzenia inwestycji w Unii Europejskiej zgodny z promowaną ideą reindustrializacji gospodarki europejskiej. Przyją on potoczną nazwę Planu Junckera. Fundusz EFSI, posiadając gwarancje z budżetu europejskiego oraz środki pochodzące z Europejskiego Banku Inwestycyjnego (EBI) ma w latach 2015-2017 do dyspozycji 21 mld euro (w tym 16 mld euro w formie gwarancji budżetowych i $5 \mathrm{mld} \mathrm{z}$ EBI). Wygenerować ma przychody rzędu minimum $315 \mathrm{mld}$ euro. Będą to długoterminowe inwestycje sektora prywatnego o wartości $240 \mathrm{mld}$ euro oraz inwestycje małych i średnich przedsiębiorstw na kwotę 75 mld euro. Efekt mnożnikowy obliczono więc na poziomie $1: 15$, czyli każde 1 euro zapewnione przez fundusz ma wygenerować dodatkowe inwestycje o wartości 15 euro. Środki z EFSI bezpośrednio inwestowane będą w wybrane strategiczne projekty infrastrukturalne ze szczególnym uwzględnieniem energii, transportu i technologii informacyjno-komunikacyjnych oraz obronności. Według szacunków Komisji Europejskiej proponowane środki w ujęciu łącznym mogłyby przynieść wzrost unijnego PKB o 330-410 mld euro w trzech najbliższych latach $\mathrm{i}$ umożliwić stworzenie nawet $1,3 \mathrm{mln}$ nowych miejsc pracy. Plan Junckera umożliwić ma osiagnięcie trzech powiązanych ze sobą celów, jakimi są:

- odwrócenie spadkowych tendencji inwestycyjnych oraz zapewnienie dodatkowych impulsów do tworzenia miejsc pracy i ożywienia gospodarczego, bez obciążeń dla krajowych finansów publicznych lub tworzenia nowego zadłużenia; 
- podjęcie decydujących działań w kierunku zaspokajania długoterminowych potrzeb europejskiej gospodarki oraz zwiększenia jej konkurencyjności;

- wzmocnienie europejskiego wymiaru kapitału ludzkiego, zdolności produkcyjnej, wiedzy i infrastruktury fizycznej, ze szczególnym naciskiem na połączenia międzysystemowe o istotnym znaczeniu dla Jednolitego Rynku (EU rozpoczyna; An Investment).

Mimo, że krytycy najnowszego pomysłu KE najczęściej nazywają go „kreatywną księgowością" i ,inżynierią finansową", która przelewa środki finansowe z jednej pozycji budżetowej Unii (EU general budget) do drugiej, nie generując nowych, jest to bez wątpienia ciekawa i oczekiwana przez rynki światowe koncepcja pobudzenia wzrostu gospodarczego w Europie. Z perspektywy połowy 2015 roku wyjątkowo trudno prognozować jednak skuteczność jego realizacji. Plan Junckera ewidentnie wymaga doprecyzowania pod kątem odpowiedzi na liczne pytania i wątpliwości stawiane przez państwa członkowskie UE, w tym pochodzące z Polski. Nie ma też żadnej gwarancji, że przewidywany poziom zwielokrotnienia wydatków inwestycyjnych, głównie prywatnych (private equity/venture capital) w UE szacowany jako efekt mnożnikowy 1:15 w ogóle okaże się realny (EU rozpoczyna; An Investment; Polska stawia).

Z kolei program COSME stanowi kontynuację Programu ramowego na rzecz konkurencyjności i innowacji CIP (Competitiveness and Innovation Framework Programme) realizowanego w latach 2007-2013. Stworzono go przede wszystkim w celu promowania konkurencyjności sektora MŚP poprzez wsparcie działalności innowacyjnej (w tym innowacji ekologicznych), zapewnienie lepszego dostępu do środków finansowych oraz świadczenia na poziomie regionalnym usług wsparcia dla biznesu. Głównym celem programu COSME jest wzmocnienie konkurencyjności i trwałości unijnych przedsiębiorstw, szczególnie z sektora MŚP, krzewienie kultury przedsiębiorczości i wspieranie tworzenia miejsc pracy w tym sektorze. Szczególną uwagę zwraca on na mikroprzedsiębiorstwa, przedsiębiorstwa rzemieślnicze, osoby samozatrudnione, wolne zawody oraz przedsiębiorstwa ze sfery ekonomii społecznej, typu fundacje i stowarzyszenia. Budżet programu stanowi kwota 2,3 miliarda euro, z czego co najmniej $60 \%$ (1,4 mld euro) przeznaczone zostanie na różne instrumenty finansowe. W latach 2014-2020 w ramach COSME dostępne będzie więc wsparcie dla konkurencyjności oraz sektora MŚP. Wsparcie działalności innowacyjnej prowadzone będzie w ramach analizowanego programu Horyzont 2020 (Rozporzadzenie).

\section{Podsumowanie}

Zarówno samą ideę reindustrializacji gospodarki europejskiej, jak i omówione inicjatywy służące jej realizacji ocenić należy pozytywnie. Żałować jedynie wypada, że tak późno Komisja Europejska, a w ślad za nią rządy państw członkowskich UE, doszły do wniosku, że dochodzenie do modelu ,gospodarki opartej na wiedzy" i „społeczeństwa informacyjnego" z dominującą rolą usług wiedzochłonnych powinno mieć charakter bardziej ewolucyjny niż rewolucyjny i nie może obejść się bez nowoczesnego, coraz bardziej zrobotyzowanego i zautomatyzowanego przemysłu. Szczególnie jest to istotne w dobie nieuczciwych chińskich praktyk w handlu międzynarodowym i ros- 
nącej konkurencji przemysłowej Państwa Środka w sferze nowoczesnej produkcji. Przejście od modelu gospodarki rolnej do przemysłowej w rozwiniętych gospodarkach w świecie wymagało wielu stuleci. Od czasów pierwszej rewolucji przemysłowej w gospodarce światowej i jej kluczowych wynalazków, do czasów drugiej rewolucji w sferze przemysłu i jej osiągnięć technologicznych, gospodarczych, społecznych i kulturalnych minęło kolejne sto kilkadziesiąt lat. Postindustrialny model rozwoju społeczno-gospodarczego oparty na e-ekonomii i dominującej roli usług zapewne pozostanie wiodącym kierunkiem działań w świecie państw średnio- i wysokorozwiniętych, ale jego spełnienie dotyczyć będzie bardziej odległej przyszłości niż pierwotnie zakładano. Realizacja tej wizji trwać będzie dekady, czyli znacznie dłużej niż choćby w Strategii Lizbońskiej z 2000 roku planowano. Europa, jeszcze długie dziesięciolecia może być silna i konkurencyjna gospodarczo w świecie, przez pryzmat rosnącej wagi, znaczenia i nowoczesności swego przemyshu. Programy autorstwa Komisji Europejskiej działania reindustrializacyjne mogą inicjować, stymulować i współfinansować. Nie wyręczą one jednak rządów państw członkowskich Unii w priorytetowym postrzeganiu idei reindustrializacji w swej polityce gospodarczej. Unii Europejskiej ze względu na status organizacji międzynarodowej o charakterze integracyjnym, o wyjątkowo małej, jak na miarę potrzeb, zdolności finansowej w realizacji celów ponadnarodowych oraz typie współpracy opartym głównie na porozumieniach międzyrządowych, trudniej jest - w porównaniu z federacyjnym modelem amerykańskim czy autorytarnym kapitalizmem chińskim - skutecznie wdrażać nawet najbardziej pożądane idee i pomysły. Fakt ten nie oznacza jednak, że z góry, w rywalizacji o światowe rynki, skazana jest ona na porażkę.

\section{Bibliografía}

An Investment Plan for Europe, http://ec.europa.eu/priorities/jobs-growth-investment/plan/docs/invest_in_europe_en.pdf, 28.03.2015.

Mann C. L., OECD chief economist, Putting the euro area on a road to recovery, OECD Economic Outlook 2014, Paris, 25 $5^{\text {th }}$ November 2014, http://www.oecd.org/eco/outlook/economicoutlook.htm, 25.11.2014.

Dziatania na rzecz odrodzenia przemysh europejskiego - Bruksela, dnia 22.1.2014 r. COM(2014) 14 final, komunikat Komisji do Parlamentu Europejskiego, Rady, Europejskiego Komitetu Ekonomiczno-Spolecznego i Komitetu Regionów \{SWD(2014) 14 final\} - Komisja Europejska.

EU rozpoczyna ofensywe inwestycyjna, aby pobudzić wzrost $i$ tworzenie miejsc pracy, Strasburg. 26 listopad 2014, Komisja Europejska - komunikat prasowy, europa.eu/rapid/press-release_IP-14-2128 pl.pdf, 14.04.2015.

European Competitiveness Report 2014 Helping Firms Grow - Commission Staff Working Document SWD(2014)277 final, European Union, 2014.

Horizon 2020 w skrócie - Program ramowy UE w zakresie badań naukowych i innowacji, Komisja Europejska: 2014 Dyrekcja Generalna ds. Badań Naukowych i Innowacji, Dyrekcja Generalna ds. Badań Naukowych i Innowacji, Urząd Publikacji Unii Europejskiej, Luksemburg 2014. 
Horyzont 2020 - program ramowy w zakresie badań naukowych i innowacji - Komisja Europejska - Bruksela, dnia 30.11.2011 KOM(2011) 808 wersja ostateczna; komunikat Komisji do Parlamentu Europejskiego, Rady, Europejskiego Komitetu Ekonomiczno-Spolecznego i Komitetu Regionów (tekst mający znaczenie dla EOG), \{SEK(2011) 1427 wersja ostateczna\} \{SEK(2011) 1428 wersja ostateczna\} PL 2 PL 1.

Juncker J.-C. (kandydat na urząd przewodniczącego Komisji Europejskiej), Nowy poczatek dla Europy: Mój program na rzecz zatrudnienia, wzrostu, sprawiedliwości oraz zmian demokratycznych. Wytyczne polityczne na następna kadencję Komisji Europejskiej. Strasburg, 15 lipca 2014 r.

Konkurencyjność przemyslu: w sprawozdaniach Komisji podkreśla się konieczność podjęcia bardziej zdecydowanych dzialań przez UE i państwa czlonkowskie, Komisja Europejska - komunikat prasowy, Bruksela, 11 września $2014 \mathrm{r}$.

Macierewicz P., $W$ poniedzialek EBC rozpocznie druk euro, http:/wyborcza.biz/biznes/ $1,100896,17526243$,W_poniedzialek_EBC_rozpocznie_druk_euro.html\#ixzz3UMzohFz4, 6.03.2015.

Najpierw myśl na malq skale - program ,, Small Business Act” dla Europy, komunikat Komisji do Rady, Parlamentu Europejskiego, Europejskiego Komitetu Ekonomiczno-Spolecznego i Komitetu Regionów - Komisja Wspólnot Europejskich \{SEK(2008) 2101\}, \{SEK(2008) 2102\} Bruksela, dnia 25.6.2008 KOM(2008) 394 wersja ostateczna.

OECD: stagnacja $w$ strefie euro zagraża calemu światu, http://www.forbes.pl/oecd-stagnacja-w-strefie-euro-zagraza-calemu-swiatu, 25.11.2014.

Opinia Europejskiego Komitetu Ekonomiczno-Społecznego w sprawie: Silniejszy przemyst europejski na rzecz wzrostu i ożwienia gospodarczego. Aktualizacja komunikatu w sprawie polityki przemyslowej, $\operatorname{COM(2012)~} 582$ final (2013/C 327/14), sprawozdawca: Joost Van Iersel, współsprawozdawca: Enrico Gibellieri - C 327/82 Dziennik Urzędowy Unii Europejskiej 12.11.2013

Polityka Przemyslowa - Strategia Europa, http://europa.eu/legislation_summaries/enterprise/industry/et0005 pl.htm, 14.04.2015.

Polska stawia warunki odnośnie planu Junckera, Pap, http://www.ekonomia.rp.pl/artykul/1166671.html. 22.12.2014.

Progress in industrial competitiveness per EU country, European Commission, MEMO, Brussels, 11 September 2014.

Rozporządzenie Parlamentu Europejskiego i Rady (UE) nr 1287/2013 z dnia 11 grudnia 2013 r. ustanawiajace program na rzecz konkurencyjności przedsiębiorstw oraz matych $i$ średnich przedsiębiorstw (COSME) (2014-2020) i uchylajace decyzję nr 1639/2006/WE (tekst mający znaczenie dla EOG) 20.12.2013 Dziennik Urzędowy Unii Europejskiej L 347/33.

Society at a Glance 2014 OECD Social Indicators, OECD (2014), Society at a Glance 2014: OECD Social Indicators, OECD Publishing. http://dx.doi.org/10.1787/soc_glance-2014-en, 28.03.2015.

Strefie euro grozi dlugotrwala stagnacja gospodarcza, http://wyborcza.biz/biznes, 25.11.2014.

The Investment Plan, Questions and Answers, EC, EIB, http://ec.europa.eu/priorities/jobs-growth-investment/plan/docs/investment-plan-qa en.pdf, 28.03.2015.

World Economic Outlook, Legacies, Clouds, Uncertainties, IMF October 2014 http:/www.imf.org/ external/pubs/ft/weo/2014/02/, 28.03.2015.

Zrozumieć politykę Unii Europejskiej - przedsiębiorstwa, KE, Nowa rewolucja przemystowa, http://europa.eu/pol/index_en.htm, http://europa.eu/!ud99qu, 14.04.2015.

Żbik A., Inicjatywy JASPERS, JEREMIE i JESSICA, 23.09.2012, http://www.uniaeuropejska.org/ inicjatywy-jaspers-jeremie-i-jessica, 29.03.2015. 


\title{
Streszczenie
}

W Unii Europejskiej po kilkunastu latach iluzorycznej wiary w sukces ,gospodarki opartej na wiedzy", głównie opartej na usługach wiedzochłonnych (KIS) ze sfery e-ekonomii oraz dostrzeżeniu błędu, jakim była deindustrializacja zainicjowana pod koniec lat 80 . minionego wieku, decydenci polityczni, zarówno na poziomie państw członkowskich jak i instytucji wspólnotowych - pod hasłem reindustrializacji - postanowili wrócić do idei rozwoju nowoczesnego i konkurencyjnego przemysłu europejskiego. Deindustrializacja oznaczała przenoszenie przez europejskie korporacje pracochłonnej produkcji do ,największej fabryki świata”, czyli Chin i innych „rynków wschodzących" z Azji Południowej i Wschodniej. Wiązało się z utratą tysięcy miejsc pracy w przemyśle europejskim, rosnącym bezrobociem i niezadowoleniem społecznym. W prezentowanym tekście autor opisuje i ocenia samą ideę reindustrializacji gospodarki europejskiej, jak i omawia najważniejsze inicjatywy służące realizacji wizji nowoczesnej, innowacyjnej i przemysłowej Europy.

Slowa kluczowe: gospodarka europejska, reindustrializacja, konkurencyjność, innowacyjność, bezrobocie, kształcenie zawodowe

\section{From recession to industrialisation. A new priority in the socio-economic development of the European Union at a time of growing global competition}

\begin{abstract}
Summary
After over a dozen years of the illusory belief in the success of the „knowledge-based economy, , mainly based on knowledge-intensive services (KIS), and the e-economy development model, EU policymakers noticed the error of de-industrialisation initiated in the late 1980s. Both at the level of member states and that of European institutions - under the banner of re-industrialisation - it was decided to return to the idea of developing a modern and competitive European industry. Deindustrialisation meant that European corporations transferred their labour-intensive production to the 'largest factory of the world,' namely China and other emerging markets of South and East Asia. This was associated with the loss of thousands of jobs in European industries, increasing unemployment and social discontent. In the paper, the author describes and evaluates the idea of the re-industrialisation of the European economy and discusses the most important initiatives necessary to implement the vision of a modern, innovative and industrial Europe.
\end{abstract}

Key words: European economy, re-industrialisation, competitiveness, innovation, unemployment, vocational education 